\title{
Preliminary Study of the Effects of some Herbal Drugs on the Heamatological and Biochemical Parameter of Winster Albino Rats
}

\author{
Akintelu Sunday Adewale ${ }^{1}$, Abiola babawale Emmanuel ${ }^{1}$, \\ Ajayi Samuel Oluwakayode², Olabemiwo Ojeyemi Matthew ${ }^{1}$
}

\author{
${ }^{1}$ Department of Pure and Applied Chemistry, Ladoke Akintola University of Technology, Ogbomoso, Nigeria \\ ${ }^{2}$ Department of Chemical science, Covenant University, Otta, Nigeria
}

\begin{abstract}
The safety level of herbal drugs especially those that are produced in developing countries are of great concern to all stakeholders in health care system. The effects of aqueous extracts of five randomly selected locally produced antimalarial herbal drugs in South Western Nigeria on the biochemical and heamatological parameters of the blood of wistar albino rats were examined. Thirty three rats of both sex and of weight range $180-200 \mathrm{~g}$ were acclimatized for two weeks, after which they were randomly distributed into six groups (control,1,2,3,4 and 5 respectively) and each group containing three rats. The rats were then fed with standard animal feed (Adose animal feed) and water. Exactly $2 \mathrm{~mL}$ of the aqueous extract of each herbal drug was administered to the rats using annular syringe at doses of $200 \mathrm{mg}$ and $400 \mathrm{mg} / \mathrm{kg} / \mathrm{day}$ for a period of two weeks. At the end of the treatment, the rats were sacrificed and biochemical and heamatological analyses of their blood performed. The value of heamatological parameter examined in this study (Red blood count (RBC), Mean cell volume (MCV), Heamogobin and packed cell volume (PVC)) fell within the standard ranges but there were significant differences in all the values of heamatological parameters of control and test rats $(p<0.05)$ except PCV. All the biochemical parameters of the test rats showed a significant difference in the acid phosphatase, alkaline phosphatase and the albumin compared to the control $(\mathrm{p}<0.05)$ except total protein.
\end{abstract}

Keywords: Heamatological Parameter, Biochemical Parameter, Malaria, Herbal Drugs

\begin{abstract}
Introduction
The application of herbs and herbals drugs in health care system is as old as the creation of man. However, in the recent time, the use of herbal drugs in treatment of illnesses has grown tremendously due to some reasons, such as emergence of some illnesses which are resistance to synthetic drugs, inadequacy of medical practitioners to give prescription of commercial drugs, increasing poverty level in most of the developing countries, exorbitant price of synthetic drugs just to mention but few (Sticket et al 2005). Statistics from world health organization (WHO) shows that about $80 \%$ of the world's populations depends on plants and herbal drugs for their primary health care (Pirzada et al 2009). Herbs and herbal drugs are considered to be relatively safer and cheaper than the synthetic drugs and they require no prescription before usage (Iwu et al 1999).
\end{abstract}

Despite the acclaimed strong health benefits of most herbal drugs, their safety levels are poorly documented and the awareness of consumers and health professionals towards herbal preparations as a potential source of health damage is low Titez (2000). Taylor et al., (2001) opined that bioactive compounds derived from plants can be useful but might have some serious-dose-related side effects. Plant rich in pyrrolidine alkaloids have been linked with hepatic vennocclusive disease (Zuckerman et al 2002). Elinav et al., (2007) established an association between intake of herbal life products (natural supplements) and acute hepatitis in some patients in Israel. Apart from the toxicity of some secondary metabolites, herbs and herbal drugs are also highly susceptible to microbial and heavy metal contaminations arising from harvesting, storage and processing system (Abou- arab et al 1999). Literature information has established the presence of toxic secondary metabolites and heavy metals in herbs and herbal drugs, which may pose a great health risks to living organism upon long term exposure (Abouarab et al 1999). In the last one decade in Nigeria, there has been upsurge in the production, sale and use of herbs and herbal drugs. Regulatory activity on

This article is published under the terms of the Creative Commons Attribution License 4.0

Author(s) retain the copyright of this article. Publication rights with Alkhaer Publications.

Published at: http://www.ijsciences.com/pub/issue/2019-10/

DOI: 10.18483/ijSci.2032; Online ISSN: 2305-3925; Print ISSN: 2410-4477 
quality and safety of the herbal drugs in most African countries including Nigeria is very weak or nonexistence. Previously the concentration, source of polycyclic aromatic hydrocarbons and the cancer risk estimation of these herbal drugs has been studied (Akintelu et al., 2018). Consequent upon this, there is need for comprehensive scientific evaluation of the herbal drugs especially the locally produced ones which are found in Nigerian Market. This study therefore aimed to carry out preliminary study on acute and sub-acute toxicity of five randomly selected antimalarial herbal drugs used in South Western part of Nigeria.

Table 1: Samples and their local names

\begin{tabular}{ll}
\hline Local name of the herbal drug & Coded name \\
\hline Jedi malaria herbal drug & A \\
Original malaria herbal drug & B \\
Ogun Iba & C \\
Ogun Iba by Alhaji Raji & D \\
Ogun iba ati inurirun & E \\
\hline
\end{tabular}

Preparation of extract for haematological and biochemical parameters

The dried herbal drugs were pulverized, $400 \mathrm{~g}$ of each of the powdered herbal drugs was separately extracted with $500 \mathrm{ml}$ of $80 \%$ methanol for 48 hours using cold extraction method. The resulting mixture was filtered, the filtrate was concentrated using rotary evaporator. About $75 \mathrm{~g}$ of the crude extract was reconstituted in distilled water to give final concentrations of 200 and $400 \mathrm{mgml}^{-1}$ by dissolving 20 and $40 \mathrm{~g}$ of the extract in $100 \mathrm{ml}$ of distilled water, respectively (Ajibade and Soetan 2012).

\section{Evaluation of haematological and biochemical parameters}

Animal's source and sorting

Thirty five adult Wistar albino rats were purchased from the animal colony of the Department of Physiology, Ladoke Akintola University of Technology Ogbomoso Oyo, Nigeria. The rats were allowed to acclimatize for two weeks in the animal house of Onabisi Onabanjo University Ago Iwoye, Nigeria. Approval for the use of the animals was obtained from the Ethical Committee of Onabisi Onabanjo University Ago Iwoye for experimental purposes only.

Experimental animal for haematological and biochemical parameters

Thirty three rats of both sex and of weight range (180 - $200 \mathrm{~g}$ ) after acclimatization for two weeks were randomly distributed into six groups (groups control, 1,2,3,4 and 5), three per cage and properly fed with standard animal feed and water. After the

\section{Materials and Methods \\ Materials}

All reagents used were of analytical grade. The reagents are di- potassium ethylene di- amine tetra acetic acid ( $\mathrm{K}_{2}$ EDTA), lithium heparin. Reagents were used as received

\section{Sample collection}

Five most popularly used antimalarial herbal drugs (Nigeria products) sold in Southwest Nigeria were purchased directly from the vendors. The samples were separately oven dried, grounded and kept in separate air tight glass containers for the purpose of this study. The samples were coded as shown in Table 1 acclimatization period, the ration of the animals changed, as test rats were fed with animal feed, in addition; dosage of extract of herbal drug $3 \mathrm{~mL}$ of 200 and $400 \mathrm{mgml}^{-1}$ were orally administered to the rats in the groups 1, 2, 3, 4 and 5 with annular syringe while water and animal feed were given to the rats in the control group. The following hematological and biochemical parameters; Red blood cell (RBC), white blood cell(WBC), mean cell volume (MCV), packed volume cell (PCV), Haemoglobin (HB),Albumin (Alb),total protein, alkaline phosphatase(ALP), and acid phosphatase(ACP) were evaluated using the method of (Dacie and Lewis 1998; Olabemiwo et al 2011).

Blood collection for haematological and biochemical parameters

At the end of the experiment (two weeks after acclimatization), blood sample were collected by cardiac puncture under ether anesthesia. $10 \mathrm{~mL}$ of blood were collected from each rat; $3.0 \mathrm{~mL}$ of the blood dispensed into di potassium ethylene di amine tetra acetic acid ( $\mathrm{K}_{2}$ EDTA) an anticoagulant for haematological analysis and $7.0 \mathrm{~mL}$ into lithium heparin a coagulant for biochemical analysis.

\section{Statistical analysis}

All values were expressed as mean \pm standard error of mean (S.E.M). The means and standard error of means as well as paired sample test for statistical significance was determined using statistical package for social sciences (SPSS) version 20. P values at $\mathrm{p}<$ 0.005 were regarded as significant. 


\section{Results and Discussion}

Haematological parameters of rats ingested with the selected antimalarial herbal drugs

The heamatological parameters of the rats used in this study are as presented in Table 2 . The red blood cells (RBCs) of rats in the control group were significantly different $(p<0.05)$ from test rats. The values of the RBCs ranges from $6.08 \pm 0.61$ to $7.57 \pm 0.2310^{6} \mathrm{~mm}^{3}$ and the RBCs of the all the test rats are lower than the rats in the control group (Table 1.0). The red blood cells count in this study are within the standard range (6.23-8.7 $\left.106 \mathrm{~mm}^{3}\right)$ CACC, (1980) and similar to that of Nse et al., (2014) and Dike and Luteino (2015).This suggests that all the selected antimalarial herbal drugs may be good transporters of oxygen in the body. The decrease in the red blood cell counts in this study may be attributed to the ingested antimalarial herbal drugs extracts.

The result is in agreement with findings of Adeleye et al., (2012) on the repeated administration of antimalarial tablet called coartem. Their study showed that administration of the drug affected the blood cell counts and made users susceptible to anemia. Isaac et al. (2013) in their own study reported that a reduction in the red blood cell counts implies a decrease in the level of oxygen that would be carried to the tissues as well as the level of carbon dioxide returned to the lungs. This suggests that long time intake or repeated administration of these herbal drugs might possibly result to anemia. Therefore, excessive administration of these herbal drugs is not encouraged.

The values of the white blood cell (WBC) as shown in Table 1 ranges from $\left(7.78 \pm 0.43\right.$ to $11.32 \pm 1.55 \mathrm{gdl}^{-}$ $\left.{ }^{1}\right)$, this range is within the standard set by CACC, (1980), (Table 1.0). The values of the WBC of the rats used in this study are higher than the values obtained by Ajibade and Soetan, (2012); Olafadehan, (2011). The significant increase in total white blood cell count of test rats when compared with the control rats, and this may be attributed to the antimalarial herbal drugs extracts ingested into the rats. Earlier study by Guyton and Hall, (2006) showed that increase in WBC counts is an indication of the immunological response caused by drug Kinney et al. (1999) showed that drugs that increase WBC have an immune-protective effect which is necessary in cellular defense mechanisms in the human body. Soetan et al., (2013) also reported that animals with high white blood counts are capable of generating antibodies in the process of phagocytosis and have high degree of resistance to diseases. It is therefore suggested that the selected antimalarial herbal drugs have an immune-protective effect which may decrease the degree of susceptibility of the rats to diseases.

There is a significance difference in the mean cell volume (MCV) of rats in the control group and test rats. The maximum $\mathrm{MCV}$ value in the rats showed significant difference the level of $\mathrm{p}<0.05$. The rats in control group had highest value of $\mathrm{MCV}$ $64.34 \pm 3.65 \mathrm{fl}$ while the test rat had minimum value in $\left(200 \mathrm{mgkg}^{-1}\right)$ sample A $51.34 \pm 2.65 \mathrm{fl}$ (Table 2.0). The values of mean cell volume of test rats fall within the standard range set by CACC, (2001). The values are also in line with values obtained by (Iwona and Eugeniusz 2014; Dike and Lutein, 2015) in their studies. It can therefore be inferred that consumption of any of the herbal drugs used in this study may not have negative impact on the quantum of MCV in the animal. This suggests that the consumption of these herbal drugs may have no harmful effect on the red blood cell size.

There is no significant different $(p>0.05)$ between the packed cell volume (PCV) of the test rats and the rats in the control group. The average value of packed cell volume of the test rats is in the range of the reference standard and similar to the result from the studies of Obianime et al., (2011). Sembullinga and Sembullinga (2012) opined that the value of packed cell volume can be polycythemia indicator in animal. On basis of this, none of the herbal drugs used in this study can induce anemia and polycythemia.

There is a significantly difference between the values of haemoglobin of the rats in the control group and the test rats $(p<0.05)$. However, the values of haemoglobin of the test rats are within the range of the reference standard set by CACC and also in agreement with the results obtained by (Kandeepan, 2014; Dike and Luteino, 2015).

Nse, et al., (2014) reported that haemoglobin performs the function of transporting oxygen to tissues of the animal for oxidation of ingested food so as to release energy for the other body functions as well as transport carbon dioxide out of the body of animals. Sembullinga and Sembullinga (2012) stated that hemoglobin enhances the functionality of the respiratory system and also aid the regulation of acid/base balance in the body. This might be responsible for the acclaimed efficacy of these herbal drugs by the locals.

\section{Biochemical parameters of rats ingested with the selected antimalarial herbal drugs}

There was a significant difference in the acid phosphatase and alkaline phosphate content in the blood of rats ingested with the selected antimalarial herbal drug extracts and the rats in the control group 
( $>>0.05)$, Table 2.0. At the two concentration levels (200 and $400 \mathrm{mg} / \mathrm{kg}$ ) used in this study, the values of ALP of the test rats were found to be lower than that of the control rats. Similarly, the values of the ACP of all the test rats were lower than that of the control rats except test rats that were injected with $200 \mathrm{mg} / \mathrm{kg}$ of sample C and $400 \mathrm{mg} / \mathrm{kg}$ of sample D Oluduro and Aderiye, (2009) obtained similar result for rats which they injected with extracts from moringa.

Increase in concentration of ACP and ALP in the serum of animal is an indication of a major permeability, injection or cell rupture which leads to release of these enzymes to the blood. In other words, liver damage causes leaking of ALT, AST and acid phosphatase into the blood stream, Tedong et al., (2008). Thus, assessment of liver function test can be done by estimating the activities of serum ALT, AST and Acid phospotase (Neera et al., 2013). The decrease in the acid phosphatase and alkaline phosphatase in the blood of the rats ingested with these herbal drug extracts implies that administration of these herbal drugs might not cause serious impairment to liver function.

The values of creatinine in the blood of rats in the control group and the ingested rats were significant different $(\mathrm{p}<0.05)$. The lowest value of creatinine in this study was found in rats ingested with $400 \mathrm{mg} / \mathrm{kg}$ of sample $\mathrm{E}$ and the highest was found in rats in the control group. However, the two values fell within standard range $\left(0.3-2.6 \mathrm{mgdl}^{-1}\right)$ set by CACC. Oyagbemi et al., (2013) had earlier obtained similar results for rats fed with methanolic extract of Moringa oleifera leaves in liver and kidney of male Wistar rats
Oyagbemi et al., (2013b) reported a significant reduction in both serum creatinine and urea in rats exposed to prolonged administration of methanolic extract of Moringa oleifera and suggested that methanolic extract of Moringa oleifera has no toxic effect on the kidney. Creatinine level in the serum is taken as an index of nephrotoxicity, Ali et al., (2001). Therefore, the reduction in the value of creatinine in this study suggests that the use of these herbal drugs might not be toxic to the kidney.

The total protein in the blood of rats in the control group and the test rats are significantly different $(\mathrm{p}<0.05)$. The lowest total protein in this study was found in the blood of the rats in the control group $\left(4.20 \mathrm{~g} / 100 \mathrm{~cm}^{3}\right)$ and highest in blood of rats that was ingested with $200 \mathrm{mgkg}^{-1}$ of sample D extract $\left(6.28 \mathrm{~g} / 100 \mathrm{~cm}^{3}\right)$. However, the range of total protein in this study $\left(4-7 \mathrm{~g} / 100 \mathrm{~cm}^{3}\right)$ fell within the range set by CACC. The concentration of total protein in this study was lower than that obtained by Ajibade, and Soetan (2012). This variance in the blood of rats might be attributed to the ingested herbal drug extracts.

The slightly higher concentration of total protein in the blood of test rats compared to the rats in the control groups but the values fell within normal limits. They might be due to the fact that the medicinal plants from which the herbal drugs are made are rich in protein, which may increase the amount of protein in the diet, and thus in the blood, Ajibade, and Soetan (2012). This suggests that these herbal drugs possess good nutritional value. However, the possibility of the extract having deleterious effects on the internal organs of the body at high doses, or when used for longer duration, cannot be ruled out.

Table 2.0: Haematological parameters of rats ingested with the selected antimalarial herbal drugs

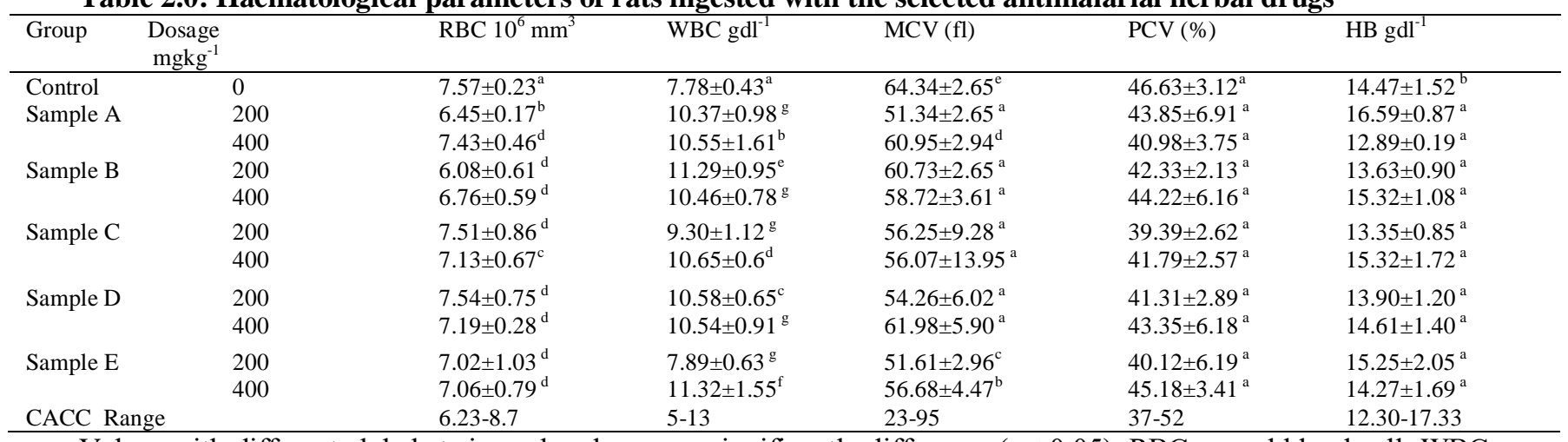

Values with different alphabets in each column are significantly difference $(\mathrm{p}<0.05) . \mathrm{RBC} \rightarrow$ red blood cell, WBC $\rightarrow$ white blood cell, $\mathrm{CCAC} \rightarrow$ Canada Council of Animal Care,MCV $\rightarrow$ mean cell volume, PCV $\rightarrow$ packed volume cell and $\mathrm{HB} \rightarrow$ Hemoglobin. 
Preliminary Study of the Effects of some Herbal Drugs on the Heamatological and Biochemical Parameter of Winster Albino Rats

\begin{tabular}{|c|c|c|c|c|c|}
\hline Group & $\begin{array}{l}\text { Dosage } \\
\mathrm{mgkg}^{-1}\end{array}$ & $\mathrm{ACP}\left(\mathrm{IUL}^{-1}\right)$ & $\begin{array}{c}\text { ALP } \\
\left(\mathrm{IUL}^{-1}\right)\end{array}$ & $\begin{array}{c}\text { Creatinine } \\
\text { mgdl }^{-1}\end{array}$ & $\begin{array}{l}\text { Total Protein } \\
\mathrm{g} / 100 \mathrm{~cm}^{3}\end{array}$ \\
\hline Control & 0 & $158.25 \pm 1.90^{\mathrm{f}}$ & $41.87 \pm 4.08^{i}$ & $1.45 \pm 0.27^{\mathrm{d}}$ & $4.20 \pm 0.22^{b}$ \\
\hline \multirow[t]{2}{*}{ Sample A } & 200 & $135.73 \pm 4.87^{\mathrm{a}}$ & $32.20 \pm 2.08^{f}$ & $0.90 \pm 0.42^{\mathrm{a}}$ & $6.03 \pm 0.81^{b}$ \\
\hline & $\begin{array}{l}400 \\
200\end{array}$ & $\begin{array}{l}135.73 \pm 4.87^{\mathrm{a}} \\
141.30 \pm 3.04^{\mathrm{b}}\end{array}$ & $\begin{array}{l}32.20 \pm 2.08^{\mathrm{e}} \\
31.87 \pm 4.75^{\mathrm{d}}\end{array}$ & $\begin{array}{l}0.83 \pm 0.4^{b} \\
0.81 \pm 0.19^{b}\end{array}$ & $\begin{array}{l}5.49 \pm 0.32^{\mathrm{f}} \\
5.05 \pm 0.25^{\mathrm{b}}\end{array}$ \\
\hline \multirow[t]{2}{*}{ Sample C } & $\begin{array}{l}400 \\
200\end{array}$ & $\begin{array}{l}154.58 \pm 3.98^{\mathrm{e}} \\
160.95 \pm 3.07^{\mathrm{h}}\end{array}$ & $\begin{array}{l}32.22 \pm 1.94^{\mathrm{g}} \\
28.98 \pm 3.03^{\mathrm{c}}\end{array}$ & $\begin{array}{l}0.86 \pm 0.57^{\mathrm{b}} \\
0.96 \pm 0.70^{\mathrm{a}}\end{array}$ & $\begin{array}{l}5.44 \pm 0.68^{\mathrm{e}} \\
4.80 \pm 0.40^{\mathrm{a}}\end{array}$ \\
\hline & $\begin{array}{l}400 \\
200\end{array}$ & $\begin{array}{l}142.51 \pm 4.32^{\mathrm{d}} \\
139.66 \pm 1.46^{\mathrm{a}}\end{array}$ & $\begin{array}{l}31.84 \pm 7.28^{\mathrm{c}} \\
36.23 \pm 1.91^{\mathrm{h}}\end{array}$ & $\begin{array}{l}0.92 \pm 0.11^{\mathrm{a}} \\
0.73 \pm 0.47^{\mathrm{c}}\end{array}$ & $\begin{array}{l}5.22 \pm 0,38^{d} \\
6.28 \pm 0.18^{b}\end{array}$ \\
\hline Sample D & 400 & $161.19 \pm 3.95^{\mathrm{i}}$ & $24.60 \pm 1.55^{b}$ & $0.85 \pm 0.10^{b}$ & $5.67 \pm 0.79^{b}$ \\
\hline \multirow[t]{2}{*}{ Sample E } & 200 & $133.70 \pm 4.04^{\mathrm{a}}$ & $28.99 \pm 3.03^{c}$ & $0.75 \pm 0.31^{\mathrm{c}}$ & $5.28 \pm 0.96^{\mathrm{b}}$ \\
\hline & 400 & $141.99 \pm 4.07^{\mathrm{c}}$ & $32.11 \pm 1.61^{\mathrm{a}}$ & $0.71 \pm 1.07^{\mathrm{c}}$ & $5.20 \pm 0.30^{\mathrm{c}}$ \\
\hline \multicolumn{2}{|c|}{ CACC Range } & $25.9-44.2$ & $57-128$ & $0.3-2.6$ & $4-7$ \\
\hline
\end{tabular}

Values with different letters in the column are significantly different $(\mathrm{p}<0.05)$. ALP $\rightarrow$ alkaline phosphatase, CCAC $\rightarrow$ Canada Council of Animal Care) and ACP $\rightarrow$ Acid phosphatase.

\section{Conclusion}

Preliminary toxicological investigation of the five herbal drugs (Jedi malaria herbal drug, Original malaria herbal drug, Ogun Iba, Ogun Iba by Alhaji Raji and Ogun iba ati inurirun) showed that the heamatological and biochemical parameters of the white rats ingested with extract of these drugs were altered. The acute toxicity of the studied herbal drugs showed their safety at the studied dosage 200 and $400 \mathrm{mg} / \mathrm{kg}$ level. However, caution should be taken in the use of these herbal drugs as prolonged administration might result to hepatotoxicity and renal problem.

\section{Acknowledgement}

The Authors acknowledge Mr. Akanji SB, Department of Pure and Applied Chemistry Research Laboratory, LAUTECH, for his technical assistance in this work.

\section{Reference}

1. Abou-Arab A..K, Kawther M. S , El Tantawy M.E., Ismail Badeaa R., Naguib Khayria(1999) Quantity estimation of some contaminants in commonly used medicinal plants in the Egyptian market. Food Chemistry 67 (1999) 357-363

2. Adeleye G.S, Nneli R.,Nwozor C.M and Emesiana M.C (2012) Effects of Coartem and Artesunate on Some Haematological and Biochemical Parameters in Albino Rats Afr. J. Biomed. Res. Vol.15; 55 - 581

3. Ajibade, T. O. and Soetan, K. O (2012) Evaluation of haematological and plasma biochemical effects of aqueous extracts of Parkiabiglobosa seeds in rats. African Journal of Biotechnology Vol. 11(88), pp. 15446-15450

4. Akintelu S.A, Abiola B E., Ajayi S O. and Olabemiwo OM. (2018) Quantification and Preliminary Estimation of Toxic Effects of Polycyclic Aromatic Hydrocarbon in some Antimalarial Herbal Drugs in Southwest Nigeria. Bulletin of Pharmaceutical Research 8(1):152

5. Ali, D.A., A.M. Abdeen, M.F. Ismail and M.A. Mostafa, 2013. Histological, ultrastructural and immunohistochemical studies on the protective effect of ginger extract against cisplatin-induced nephrotoxicity in male rats. Toxicol. Ind. Health.

6. Canada Council of Animal Care (CCAC) (1980) Guide to the care of experimental animal.1:95-96

7. Dacie J.V and Lewis S.M, (1984) Practical Haematology. Churchill livingstoneNewyork USA PP 202-453.

8. Dike E.C and Luteino L.H (2015). Effect of Aqueous Extract of MoringaOleifera Seed on Haematological Parameters and the Spleen in Male Albino Rats. IOSR Journal of Dental and Medical Sciences e-ISSN: 2279-0853, p-ISSN: 22790861. Volume 14, PP 35-41

9. Elinav, E., Pinsker, G., Safadi, R., Pappo, O., Bromberg, M., Anis, E. (2007). Association between consumption of Herbalife-nutritional supplements and acute hepatotoxicity. J Hepatol, 2007, 47, 514-520

10. Guyton, A.C. and Hall, J.E. (2006) Textbook of Medical Physiology. 11th Edition, Elsevier Saunders, Amsterdam.

11. Isaac, L. J., Abah, G., Akpan, B. and Ekaette, I. U. (2013). Haematological properties of different breeds and sexes of rabbits. Proc. of the 18th Annual Conf. of Anim. Sci. Assoc. of Nig., 24-27.

12. Iwona $\mathrm{R}$ and Eugeniusz $\mathrm{H}$ (2014) Hematological and biochemical blood parameters in dairy cows depending on the management system Animal Science Papers and Reports vol. 32 (2014) no. 4, 317-325

13. Iwu M.M, Duncan A.R, Okunji C.O (1999). New Antimicrobials of plant origin. In Janick, J. (ed) Perspectives in New crops and New uses. ASHS Press, Alexandria, V.A. pp 457-462

14. Kandeepan c (2014) Effect of Stress on Haematological Parameters of Air Breathing Loach Lepidocephalusthermalis(Cuv\&Val). International journal current research and academic review 2(8): Pg 309-322

15. Kinney T.R, Ronald W, Helms E.E, Branski K.O (1999). Safety ofhydroxy Urea in children with sickle cell anaemia: Results of the HUG-KIDS study, a phase I/II trial. Blood 5:1550-1554.

16. Neera S, Poonam R, Gupta M, Nidhi G and Neeraj T(2013) Effects of aqueous extract of Camellia sinensis (1.) O.kuntze on liver markers of cadmium treated rats. E3 Journal of Biotechnology and Pharmaceutical Research Vol. 4(5), pp. 89-93.

17. Nse A.N, Williams E.M, UduakA, and Edem E. A. (2014) Haematological Parameters and Factors Affecting Their Values Agricultural Science Volume 2, Issue 1 (2014), 37-47 
18. Obianime A.W, Aprioku J.S and Escmonu C (2011).The Effects of Aqueous Ocimum gratissimum Leaf Extract on Some Biochemical and Hematological Parameters in Male Mice. Asian Journal of Biological Sciences .4(1);44-54

19. Olabemiwo O.M, AdediranG.O,Adekola F.A, Olajire A.A and Adedeji O.S (2011) Impacts of simulatedAgbabu bitumen leachate on haematological and biochemical parameter of wistar albino rat. Research journal of environmental toxicology 5 (3): p 213-221.

20. Olafadehan O.A Changes in haematological and biochemical diagnostic Changes in haematological and biochemical diagnostic parameters of Red Sokoto goats fed tannin-rich Pterocarpuserinaceus forage diets forage diets. Vet. arhiv 81, 471-483, 2011.

21. Oluduro A. O. and Aderiye B. I. (2009) Effect of Moringaoleifera seed extract on vital organs and tissue enzymes activities of male albino rats.African Journal of Microbiology Research Vol. 3(9) pp. 537-540

22. Oyagbemi, A.A., Omobowale, T.O., Azeez, I.O., Abiola, J.O., Adedokun, R.A., Nottidge, H.O.(2013b).Toxicological evaluations of methanolic extract of Moringa oleifera leaves in liver and kidney of male Wistar rats.J Basic Clin Physiol Pharmacol.24(4):307-12

23. Pirzada, K.; Ahmad,. S. S.; Rashid, A.; Shah, I. (2009) Multivariate analysis of selected roadside plants (Dalbergia sisso and Cannabis sativa) for lead pollution monitoring. Pak. J. Bot; 41(4): 1729-1736.
24. Sembullingan K and SembullinganPrema (2012).Essentials of medical physiology. $6^{\text {th }}$ Edition; Jaypee Brothers Medical Publisher Limited. 90-153

25. Soetan KO, Akinrinde AS, Ajibade TO (2013). Preliminary studies on the haematological parameters of cockerels fed raw and processed guinea corn (Sorghum bicolor) Kubkomawa et al. 27 Proceedings of 38th Annual Conference of Nigerian Society for Animal Production, Pp. 49-52.

26. Stickel F, Patsenker E, Schuppan D (2005) Herba hepatotoxicity. JHepatol 43: 901-910

27. Taylor TN, Dolezal C, Tross S, Holmes WC. Comparison of HIV/AIDS-Specific Quality of life change in Zimbabwe Patients at Western Medicine versus Traditional African Medicine Care Sites. JAIDS. 2008;49:552-556

28. Titez N.W (2000). Fundamentals of clinical chemistry. $6^{\text {th }}$ ed Philadephia, PA: Saunders, pp 744-5, 788-9.

29. Tong Y, Yan Leng and JingLi B (2012) Chinese Herbal Medicine: a Safe Alternative Therapy for Urinary Tract Infection in Patients with Renal Insufficiency. Afr $\mathrm{J}$ Tradit Complement Altern Med. 9(2):266-270

30. Zuckerman M, Steenkamp V and M J Stewart (2002) Hepatic veno-occlusive disease as a result of a traditional remedy: confirmation of toxic pyrrolizidine alkaloids as the cause, using an in vitro technique. J Clin Pathol. 55(9): 676-679. 